\title{
Centralne planowanie i lokalne wykonanie: wyzwania wielopoziomowego systemu implementacji polityki ochrony środowiska naturalnego w Chinach
}

\begin{abstract}
Streszczenie
Ocena wdrażania polityki ekologicznej w Chinach dokonywana jest zazwyczaj w kontekście implementacji prawa ochrony środowiska. Autor proponuje odmienne podejście, zakładając, że efekty polityki uzależnione są nie tylko od takich czy innych prerogatyw na poszczególnych poziomach zarządzania, ale także od wzajemnej interakcji poszczególnych aktorów. Artykuł wskazuje, w jakim stopniu władza centralna jest w stanie definiować cele polityki, wraz z adekwatnym systemem nadzoru wdrażania, jaka jest percepcja władz lokalnych, w jakich warunkach władze lokalne są skłonne do akceptacji celów polityki ekologicznej. Zidentyfikowano, w jakich warunkach władze subnarodowe mogą zniekształcać centralnie zaplanowane działania związane z ochroną środowiska.
\end{abstract}

Słowa kluczowe: polityka publiczna, ochrona środowiska, polityka ochrony środowiska, implementacja, Chiny, multilevel governance

Kody klasyfikacji JEL: Q52, Q53, Q58, R11, R58

1 Uniwersytet Jagielloński, Instytut Bliskiego i Dalekiego Wschodu, Polska, e-mail: marek.swistak@ uj.edu.pl, https://orcid.org/0000-0001-6346-672X 


\title{
Central planning and local implementation: Challenges of the multilevel system of implementing the environmental protection policy in China
}

\begin{abstract}
The assessment of the implementation of the environmental policy in China is usually made in the context of the application of environmental law. The author proposes a different approach, assuming that the policy outcomes depend not only on such or other prerogatives at individual levels of management but on the mutual interaction of individual actors. The article indicates to what extent the central authority is able to define policy goals along with an adequate system of supervision of implementation, what is the perception of local authorities, and in what conditions local authorities are willing to accept the objectives of the ecological policy. It has been identified in which conditions sub-national authorities may distort centrally planned activities related to environmental protection.
\end{abstract}

Keywords: public policy, environmental protection, environmental policy, implementation, China, multilevel governance

JEL Classification Codes: Q52, Q53, Q58, R11, R58

Implementacja polityki ekologicznej w Chinach napotyka wiele trudności wynikających nie tylko ze złożoności materii, która dotyczy ochrony ekosystemów, ale także czynników składających się na proces jej kształtowania. Pomimo że przynajmniej od dekady można mówić o nadaniu działaniom proekologicznym wysokiego priorytetu politycznego, działania podejmowane przez ChRL są niezadowalające wobec celów stawianych przez kierownictwo Komunistycznej Partii Chin (KPCh) w tym obszarze. W literaturze przedmiotu poszukującej odpowiedzi na pytanie o przyczyny niezadowalających wyników polityki ekologicznej skupiono się w dużej mierze na implementacji prawa ochrony środowiska naturalnego. $\mathrm{W}$ niniejszym artykule proponuje się uzupełniające podejście, przyjmując za właściwą perspektywę opartą na polityce publicznej. W tym sensie zadaniem polityki nie jest li tylko implementacja prawa ochrony środowiska, ale rozwiązywanie problemów ekologicznych, względnie osiąganie założonych celów. Perspektywa polityki publicznej pozwala szerzej spojrzeć na proces implementacji polityki ekologicznej w Państwie Środka niż tylko inkorporacja krajowego prawa ochrony środowiska na poziomie wykonawczym. Jednocześnie w proponowanym ujęciu nie dezawuuje się prawa jako ważnego instrumentu implementacji omawianej polityki - nie tylko w Chinach.

W artykule skupiono się na identyfikacji wpływu relacji między władzą centralną a lokalną na efekty wdrażania polityki ekologicznej w Chinach. Na podstawie 
literatury przedmiotu (Ahlers, Heberer, 2019: 81) przyjęto założenie, że o efektach omawianej polityki nie decydują wyłącznie rozstrzygnięcia wypracowywane przez poszczególnych aktorów implementacji (centrum, władza subnarodowa, lokalne struktury administracyjne) odrębnie, a ich interakcja, co stanowi uzasadnienie odwołania się również do teorii zarządzania wielopoziomowego (multilevel governance). Zakłada się tym samym, że efekt polityki uzależniony będzie od specyfiki interakcji między głównymi podmiotami wdrażania polityki ekologicznej identyfikowanymi jako władze centralne oraz władze subnarodowe, tj. regionalne i lokalne. Znajduje to potwierdzenie $\mathrm{w}$ zaadaptowanej na potrzeby artykułu koncepcji tzw. eksperymentowania w hierarchii Heilmanna (2008: 29-30). Odwołuje się ona do wyjaśnienia adaptacji chińskiej polityki publicznej poprzez eksperymentowanie rozumiane jako niestabilne, ale produktywne połączenie zdecentralizowanego testowania instrumentów polityki z centralną ingerencją ad hoc, skutkującą selektywną integracją lokalnych doświadczeń w kształtowaniu polityki krajowej. Na podstawie tej koncepcji sformułowano kluczowe założenie artykułu odwołujące się do interakcji: władza centralna-subnarodowa, która w sposób zasadniczy determinuje kształtowanie procesu implementacji w obszarze polityki ekologicznej, jeśli weźmiemy pod uwagę chiński model zarządzania publicznego. Należy postawić następujące pytania: (1) Na ile władza centralna jest w stanie definiować cele polityki ekologicznej oraz czy formułuje adekwatny system nadzoru nad ich wdrażaniem? (2) Jaka jest percepcja władz subnarodowych (regionalnych, lokalnych) w zakresie celów polityki? (3) W jakich warunkach władze lokalne są skłonne do pełnej akceptacji idei, wizji i celów wdrażanej polityki formułowanej przez rząd centralny? (4) W jakim zakresie władze subnarodowe mogą zniekształcać działania związane z ochroną środowiska? Artykuł ma charakter problemowy, skupia się na wybranych zagadnieniach, które mają wpływ na efekty polityki ekologicznej ChRL, stąd nie przyjęto ścisłej cezury czasowej. Odwołano się jednak do polityki ekologicznej Chin kształtowanej głównie w ostatnich piętnastu latach.

W kraju o takim obszarze i liczbie ludności jak ChRL bardzo trudno o sformułowanie efektywnego systemu implementacji. Spojrzenie z perspektywy polityki publicznej na implementację polityki ekologicznej (Hill, Hupe, 2002: 41-56) w Chinach, każe się odwołać do odgórnej (top-down) teorii wdrażania polityki publicznej - kładzie się tutaj główny nacisk na zdolność decydentów do wypracowania jednoznacznych celów polityki oraz kontrolę etapu wdrażania (Parsons, 1995: 463; Hill, Hupe, 2002: 41-56). Chińska polityka ochrony środowiska odnosi się do nakazowego podejścia, w którym za wkład należy przyjąć odpowiednio sformułowaną politykę, a za efekt jej wdrożenie. W teorii odgórnego nurtu implementacji polityki odwołuje się do zasadniczej kwestii, jaką jest poziom akceptacji przez władze niższego szczebla 
(regionalne, lokalne) oraz społeczność lokalną idei, wizji, celów wdrażanej polityki sformułowanej przez rząd centralny. Brak akceptacji wymienionych elementów przez poziom lokalny oraz niemożność modyfikacji polityki publicznej w kierunku zgodnym z oczekiwaniami stanowią podstawowe przyczyny niepowodzenia publicznego działania (Smith, Larimer, 2017: 160-161). Nie należy jednak, przyjmując za właściwą odgórną teorię implementacji, pomijać wpływu podmiotów wdrażających na realizację danej polityki, co z kolei odwołuje się do teorii (bottom-up) oddolnego wdrażania polityki ekologicznej. Ten nurt analityczny procesu implementacji polityki odwołuje się bowiem do struktur biurokratycznych jako głównych aktorów realizacji polityki (Pülzl, Treib, 2007: 90-92).

Podstawą dalszego wywodu na temat interakcji poszczególnych władz jest teoria zarządzania wielopoziomowego, w ramach której przyjmuje się, że efekty polityki mogą być wynikiem interakcji między różnymi aktorami polityki - w szczególności władzą krajową a władzą regionalną (np. prowincje), lokalną (np. gminy) a innymi aktorami niepaństwowymi (np. przedsiębiorstwa, organizacje pozarządowe) (Beer, 2017). Interakcje tworzą relacje o charakterze tak wertykalnym, jak i horyzontalnym. Relacje wertykalne występują, gdy struktury lokalne wchodzą w interakcję z władzą centralną, horyzontalne natomiast gdy współdziałają z jednostkami i podmiotami na tym samym poziomie administracyjnym (Yi, Huang, Chen et al., 2019: 1-13; Ongaro, Gong, Jing, 2019: 105-120). W dalszej części artykułu jest mowa głównie o relacji władza centralna-lokalna. Dyskusja (Liu, 2003: 125-141) oparta na powyższym paradygmacie odnosi się do tego, jaki rodzaj zarządzania publicznego jest efektywniejszy: scentralizowany czy zdecentralizowany (Andersson, 2008: 71-93). Wśród argumentów przemawiających za centralizacją (Sigman, 2014: 114-130) pojawia się obawa przed zniekształceniem efektów polityki poprzez stosowanie różnic standardów ochrony, czyli lokalnych efektów ubocznych, nieakceptowalnych odmiennych standardów. Za decentralizacją przemawia bliskość władz lokalnych w stosunku do obywatela - władza lokalna ma lepszy dostęp do informacji, lepiej się orientuje w specyfice miejscowej, jest reprezentantem obywateli i odpowiada na lokalne potrzeby, jest $\mathrm{z}$ tego względu bardziej efektywna (Weibust, 2016: 7-24). Inni badacze zwracają uwagę, że nie każda forma decentralizacji (np. fiskalnej, politycznej) skutkuje sukcesem w postaci wzrostu gospodarczego (Cai, Treisman, 2006: 505-535).

Chińska polityka ekologiczna objawia się poprzez silną władzę centralną, ale jednocześnie lokalną adaptację. To także niekwestionowana pozycja państwa na etapie ustalania agendy, formułowania polityki, a przy tym nierzadko zniekształcenie w wymiarze lokalnym na etapie implementacji (Świstak, 2018: 48; Kraft, 2015: 73). Luka implementacyjna, bo tak się określa niepełne wdrażanie polityki ekologicznej, przybiera różne oblicza, m.in. wspomnianej wyżej lokalnej adaptacji, zniekształcenia 
czy też nawet innowacji (Mol, 2009: 96-100; Heilmann, 2008: 1-30). Wyraźnie należy podkreślić, że luka implementacyjna nie jest tylko specyfiką polityki ekologicznej, ale odnosi się także do rozwiązywania problemów publicznych Państwa Środka w innych dziedzinach, takich jak np. polityka społeczna (Huang, 2020: 343-364). Luka implementacyjna stanowi więc odzwierciedlenie szerszego modelu zarządzania publicznego w Chinach. W artykule skupia się uwagę na wzajemnych relacjach podmiotów kształtujących politykę w wymiarze władza centralna-subnarodowa (regionalna-lokalna). Interakcje mogą być tutaj bardziej istotne w sytuacji, w której z określonych prerogatyw dana władza nie korzysta bądź nie potrafi skorzystać (tzw. zdolność administracyjna). Nie umniejsza to roli kompetencji poszczególnych szczebli władzy (centralizacja-decentralizacja), ale powoduje przywiązywanie większej wagi do wzajemnych relacji, które w przypadku Państwa Środka są zasadniczo niesymetryczne w kierunku władzy centralnej.

\section{Zdolność władzy centralnej do kształtowania polityki ochrony środowiska naturalnego: model hierarchiczny}

Ze względu na wielkość kraju chiński rząd wdraża politykę ekologiczną poprzez rozległy system delegacji. Proces rozpoczyna się od przekazania władzy na poziom regionalny, tj. prowincji - od każdej z nich zależy wykonywanie obowiązków na ich obszarze administracyjnym. Prowincje z kolei delegują zadania na jednostki podziału terytorialnego niższego szczebla, np. gminy, i polegają na nich w wywiązywaniu się z powierzonych im obowiązków. Na każdym etapie delegacji relacja jest dwustronna, a każdy poziom zarządza tylko jednostkami podrzędnymi i pociąga je do odpowiedzialności za osiągane rezultaty. Powstała w ten sposób struktura określana jest mianem hierarchicznej, zagnieżdżonej piramidy, w ramach której zasoby są przekazywane w dól, tj. z poziomu na poziom, do którego dostarczane są określone usługi. KPCh odgrywa istotną rolę we wzmacnianiu zdolności rządu centralnego w pociąganiu do odpowiedzialności niższych szczebli struktur terytorialnych. Odbywa się to w szczególności poprzez kontrolowanie systemu mianowania i awansowania personelu, a także odpowiednią jego rotację. Niektóre badania (Heberer, 2019: 158-174) wykazały, że systemy te są skuteczne, inne, że w praktyce kadry są oceniane na podstawie zbyt wielu wskaźników, co rozprasza uwagę i odpowiedzialność lokalnych elit. Do tego dochodzi duży poziom rotacji liderów lokalnych kadr. Rotacja co 3-4 lata, która w założeniu ma promować wdrażanie centralnych dyrektyw, a rugować lokalny klientelizm i protekcję, powoduje, że lokalni liderzy myślą w perspektywie krótkoterminowej, wybierając w zakresie ochrony środowiska linię 
najmniejszego oporu (Kostka, 2014: 359-380). System poza tym opiera się na zdolności lokalnych liderów do przekonania miejscowych podmiotów m.in. do łączenia celów w zakresie efektywności energetycznej z celami wpływowych grup politycznych (Wong, Karplus, 2017: 670).

Polityka ekologiczna ewoluowała w ciągu ostatnich 15 lat aktywności mocno zdecentralizowanych jak na warunki chińskie, do powtórnej recentralizacji w ostatnich latach, zwłaszcza w okresie rządów Xi Jinpinga. Przyczyną modyfikacji polityki był fakt, że Chiny prowadziły zdecentralizowaną politykę na rzecz środowiska, a jednocześnie odnotowywały istotną jego degradację. Wszystko to za sprawą przyznania zasadniczej roli wzrostowi gospodarczemu i bogaceniu się Chin kosztem innych obszarów życia społeczno-gospodarczego, takich jak polityka społeczna, migracje czy rosnące dysproporcje rozwojowe, o ekologii nie wspominając. Zwrot polityki Pekinu w kierunku ponownej centralizacji w zakresie ekologii można odnotować $\mathrm{w}$ wyniku przebiegu XVIII zjazdu KPCh w 2012 r., kiedy ogłoszono koncepcję budowy tzw. „cywilizacji ekologicznej". Koncepcja odnosi się do kompleksowego wsparcia dla ochrony środowiska, zintensyfikowania wysiłków na rzecz ochrony przyrody, ograniczenia presji na środowisko oraz wzmocnienia systemu zarządzania służącego jako wsparcie dla postępu ekologicznego (Gacek, 2016: 77).

W ostatnich latach władza centralna zyskała na znaczeniu w implementacji polityki ochrony środowiska. Można wskazać instrumenty, które były stosowane dotychczas, a których pewna korekta w kierunku zwiększenia nadzoru z poziomu Pekinu świadczy o występowaniu trendów centralizacyjnych. Wśród tych elementów można wymienić następujące instrumenty, które jednocześnie stanowią o zdolności kreowania polityki przez rząd centralny: (1) doktryna państwa, której część stanowi idea ochrony środowiska, (2) prawo ochrony środowiska i jego standardy, (3) plany pięcioletnie oraz pochodne dokumenty strategiczne. Powyższe elementy stanowią system zarządzania polityką ochrony środowiska (POŚ) w Chinach (rysunek 1).

Doktryna państwa dotycząca ochrony środowiska naturalnego w Chinach stanowi przykład transformacji stanowiska politycznego w odniesieniu do wagi kwestii ekologicznych (Qin, 2007). Nie podlega dyskusji fakt, że od objęcia rządów przez Xi Jinpinga w 2012 r. wizerunek Chin w zakresie ochrony środowiska znacznie się poprawił. Podkreślić należy z uznaniem determinację władz $\mathrm{w}$ działaniu na rzecz odwrócenia degradacji środowiska naturalnego w Państwie Środka. Początkowa faza „zielonej transformacji” w polityce Chin była spowodowana po części nową konstelacją aktorów w zarządzaniu środowiskowym. W wymiarze wizerunkowym przynosi to rzecz jasna rezultaty, trudno jednak nie dodać, że poprzestanie tylko na deklaracjach uniemożliwi w dłuższej perspektywie egzekwowanie prawa (Kostka, Zhang, 2018: 769-781). W tym zakresie istotną rolę odgrywa zatem doktryna państwa wyrażana 
postulatami bądź hasłami typu: „zrównoważony rozwój”, „, „zysta produkcja”, „zielony PKB”, „harmonijne społeczeństwo”, „gospodarka niskoemisyjna” czy wspomniana już „cywilizacja ekologiczna”. Wszystkie one mają za zadanie obrazować konsensus polityczny na najwyższych szczeblach władzy i wskazywać zarówno centralnemu planiście, jak i lokalnym wykonawcom kierunki działania w zakresie ochrony środowiska. W rzeczywistości relacje między rządem centralnym a strukturami władz lokalnych w Chinach są o wiele bardziej złożone, niż może to sugerować koncepcja państwa unitarnego (Young, Guttman et al., 2015: 165-167).

\section{Rysunek 1. System zarządzania polityką ochrony środowiska naturalnego w Chinach}

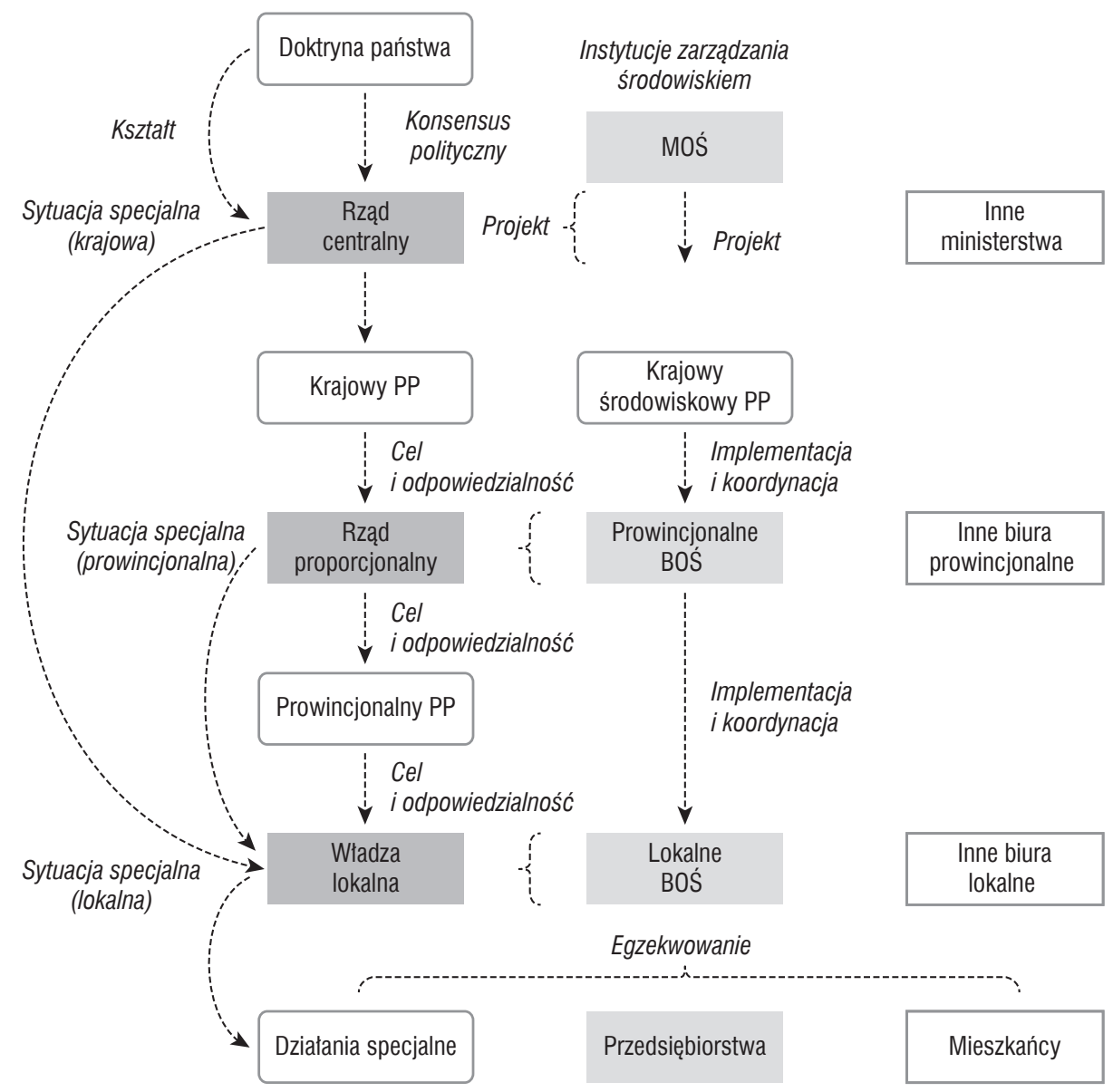

PP - Plan Pięcioletni

MOŚ - ministerstwo właściwe ds. środowiska, obecnie oficjalna nazwa to: Ministerstwo Ekologii i Środowiska BOŚ - Biuro Ochrony Środowiska

Źródło: opracowanie własne na podstawie (Jin, Andersson, Zhang, 2016: 5). 
Prawo ochrony środowiska (Zhilin, Shuchun, Bing, 2014: 8971-8973; Jin, Andersson, Zhang, 2016: 7) stanowi kolejny instrument wdrażania polityki ekologicznej istotny z poziomu oddziaływania centrum na władze niższego szczebla. Analiza literatury (Swanson, Kuhn, Xu, 2001: 481-491; Rooij, 2010: 55-79; He, Lu, Mol, Beckers, 2012: 25-38; Lorentzen, Landry, Yasuda, 2014: 182-194) wskazuje, że luka implementacyjna w zakresie wdrażania prawa ochrony środowiska wynika głównie z lokalnego protekcjonizmu. W sytuacji konfliktu norm środowiskowych z zamierzeniami czy działaniami przedsiębiorców władze lokalne decydują się na odstępstwa od skrupulatnego stosowania obowiązujących norm w zakresie ochrony przyrody.

W ostatnich latach odgórne egzekwowanie prawa stało się surowsze, świadczą o tym wprowadzane bardziej rygorystyczne przepisy krajowe i sankcje dotyczące ochrony środowiska czy też stosowanie wiążących celów środowiskowych dla lokalnych liderów, prowadzenie ogólnokrajowych kampanii egzekwowania prawa, jak również wprowadzenie scentralizowanego programu zbierania lokalnych danych dotyczących emisji - to tylko kilka przykładów (Kostka, Jonas, 2017: 575). Jednym z trendów mających wpływ na większą surowość w stanowieniu prawa było ograniczenie uznaniowości w prawie ochrony środowiska. W tym kontekście istotne stało się wprowadzanie coraz wyższych minimalnych kwot sankcji.

Nadzór prawny nad Biurami Ochrony Środowiska (BOŚ) obejmuje ponowne rozpatrzenie administracyjne lub sądowe rozstrzyganie sporów administracyjnych. Nie można jednak postrzegać tych działań jako kontroli zgodności z bardziej rygorystycznymi normami z dwóch powodów. Po pierwsze, większość spraw jest wszczynana przez zanieczyszczających przeciwko sankcjom, które często uznawane są za niesprawiedliwe lub zbyt wysokie. Po drugie, efekt odstraszający takich procedur jest bardzo niski: dane krajowe z lat 1999-2010 pokazują, że BOŚ rzadko są pociągane do odpowiedzialności w ramach tych procedur (średnio $0,4 \%$ przypadków jest rozpatrywanych ponownie, a $0,6 \%$ spraw to spory sądowe). Nawet jeśli dojdzie do wykorzystania wskazanych instrumentów, BOŚ często wygrywają. Przykładowo 65\% spraw ponownego rozpatrzenia administracyjnego oraz $95 \%$ sporów sądowych zakończyło się pozytywnym rozstrzygnięciem dla BOŚ (Rooij, 2006: 151-156). Oprócz kontroli prawnych istnieje system biurokratycznych kontroli BOŚ wyższego szczebla nadzorujących prace wykonawcze na niższych poziomach. Tutaj wyższe BOŚ cierpią na asymetrię informacji, ponieważ nie mają dokładnej wiedzy, co się dzieje w codziennych praktykach egzekwowania prawa w podległych im BOŚ (Rooij, 2003: 36-65).

Innym obszarem, na którym można identyfikować zdolność władzy centralnej do kształtowania polityki ekologicznej, jest centralne planowanie rozwoju, które obejmuje także kwestie ekologiczne. Planowanie środowiskowe w Chinach jest nierozerwalnie związane z planami pięcioletnimi - PP (Świstak, 2019: 130-136; Melton, 
2013: 1-39) i stanowi ważny instrument polityki ochrony środowiska (art. 89 Konstytucji ChRL - Constitution, 2004). Począwszy od VI planu pięcioletniego kwestie środowiskowe stały się częścią odrębnych rozdziałów i w kolejnych edycjach planów nabierają coraz to większego znaczenia (Andersson, 2016: 8). Z punktu widzenia funkcjonowania systemu należy przypomnieć, że rząd centralny zleca realizację przyjętych celów niższym szczeblom władz. Czyni tak za pośrednictwem dyrektyw, w których nie tylko definiuje wskaźniki planowanych zamierzeń, ale i przypisuje alokacje zasobów określonym celom wraz z przypisaniem odpowiedzialności za ich realizację po stronie danych jednostek administracji. W ten sposób PP stają się instrumentem, za pomocą którego w zakresie ekologii następuje transpozycja wymogów centralnych na poziom władz niższego szczebla (Guttman, Song, 2007: 425-429; Ang, 2017: 282-283).

Działania podejmowane przez władze centralne wobec lokalnego protekcjonizmu ukierunkowane są na zmianę motywacji lokalnych liderów w kierunku przestrzegania norm środowiskowych. Ochrona środowiska w karierze urzędniczej (Zhou, 2005: 1743-1762) stanowiła w najlepszym razie sprawozdanie z wykonania tzw. miękkich celów, czyli takich, których pomiar stopnia realizacji nie miał charakteru jednoznacznego. W rezultacie urzędnicy lokalni dążyli do wzrostu PKB, aby zmaksymalizować swoje szanse awansowe. Dopiero w XI planie pięcioletnim na lata 2006-2011 wprowadzono twarde cele w zakresie redukcji emisji, takie jak np. 10-procentowa redukcja dwutlenku siarki. We wskazanym planie dokonano przesunięcia odpowiedzialności za osiąganie celów środowiskowych na liderów agencji regulacyjnych, a także na najniższy poziom lokalny (Ran, 2013: 17-39). Ustalenie twardych celów może zmniejszyć lukę implementacyjną, ale należy tutaj pamiętać o komplementarności ustanawianych celów. Tymczasem cele gospodarcze nierzadko są rozbieżne z celami ochrony środowiska.

\section{Lokalna adaptacja jako luka implementacji polityki ochrony środowiska naturalnego Chin}

Lokalne struktury administracyjne mimo zwiększenia centralizmu w polityce ekologicznej nadal pozostają heterogeniczne, jeśli chodzi o motywację czy zdolności do pełnej implementacji standardów ochrony środowiska. Należy dodać, że prezentuje się to różnie w zależności od poszczególnych władz lokalnych (szczebel), a także obszarów (mniej lub bardziej zamożne jednostki). Nadal w sytuacji konfliktu interesów ekonomicznych ze środowiskowymi nie zawsze w egzekutywie zyskują te drugie (Monti, 2016: 151-152). Jest to po części wypadkową poziomu zamożności 
danego regionu. W biedniejszych obszarach ciągle przeważa kalkulacja ekonomiczna (wzrost gospodarczy, nowe miejsca pracy, przychody podatkowe itp.) nad wymogami egzekwowania przepisów i standardów ochrony środowiska (Kostka, Nahm, 2017: 569-570). Władza lokalna w ramach chińskiego autorytaryzmu zdecentralizowanego nadal ma pewne pole manewru.

Pomimo wysiłków Pekinu, aby usprawnić i scentralizować zarządzanie polityką ochrony środowiska, efekty są ciągle ograniczone. Jak wspomniano wyżej, cele ekologiczne stały się warunkiem ewentualnego awansu w systemie ocen kadr (tzw. cele veto). W rzeczywistości liczba sekretarzy KPCh, którzy faktycznie wyznaczają cele środowiskowe jako najwyższe priorytety, w ocenie wyników administrowania lokalnych kadr jest nadal przedmiotem dyskusji. Przypadki, w których lokalnego sekretarza KPCh obwiniono lub ukarano za problem z ochroną środowiska na obszarze jego jurysdykcji, należą do rzadkości. Trzeba jednocześnie zwrócić uwagę, że to, czy lokalny sekretarz KPCh zostanie rzeczywiście pociągnięty do odpowiedzialności za zarządzanie środowiskowe, będzie zależeć od tego, jak łatwo jest przerzucić winę za wszelkie niepowodzenia na inne podmioty lub instytucje. Najczęściej jednostką, na którą zwraca się uwagę w kontekście odpowiedzialności za lukę wdrożeniową, jest lokalny BOŚ. Tymczasem jest to instytucja o słabej pozycji w lokalnej strukturze władzy. Urzędnicy BOŚ zachowują pewien poziom niezależności oraz pewne zasoby, co utwierdza w przekonaniu, że organ ten odpowiada za wdrażanie polityki ekologicznej. Jest tak mimo faktu, iż na poziomie lokalnym występuje ponad 10 podmiotów publicznych i instytucji, które odpowiedzialne są za wybrane zagadnienia związane z zarządzaniem środowiskiem (Ran, 2017: 644).

Nie dziwi więc, że w odbiorze społecznym BOŚ postrzegane są jako instytucje mało efektywne, niereagujące na zgłoszone przypadki zanieczyszczeń. Media również przedstawiają urzędników w niekorzystnym świetle jako osoby, które nie są w stanie zadbać o przyrodę (np. czystość rzek). Zdarzają się także publiczne oskarżenia o poważne naruszenia dyscypliny urzędniczej oraz łamanie prawa. Same BOŚ świadome oskarżeń o niepowodzenia zachowują się trojako. Po pierwsze, przenoszą odpowiedzialność na niedostatki organizacji całej polityki ochrony środowiska w kraju (konieczność balansowania między potrzebami ekonomicznymi a ekologicznymi). Po drugie, skierowują uwagę na inne podmioty czy agencje także odpowiedzialne za środowisko. Po trzecie, przenoszą odpowiedzialność za zanieczyszczenie na lokalnych mieszkańców czy społeczeństwo (balansowanie między oczekiwaniami liderów politycznych a potrzebami obywateli, między zanieczyszczającymi a ofiarami zanieczyszczeń, poszukiwanie równowagi między wymogami władzy centralnej a przeciwnymi oczekiwaniami mieszkańców) (Ran, 2017: 645). 
Analizując lokalną adaptację, należy wspomnieć o ograniczonych wydatkach na ochronę środowiska, głównie w zakresie utrzymania sprawnego systemu administracyjnego egzekwowania ustalonych norm. Wydatki na ten cel są ściśle powiązane z dochodami władz lokalnych (np. na poziomie powiatów czy miast), które są bardzo ograniczone. Pierwszeństwo zyskują wydatki związane z lokalnymi planami rozwoju gospodarczego, co sprowadza się do tego, że władze lokalne pokrywają 70\% wydatków krajowych, przy jedynie 50-procentowym udziale w przychodach całych finansów publicznych (nie wliczając w to tzw. płatności transferowych $z$ budżetu centralnego na poziom lokalny) (Ministry of Finance, 2011). Deficyt budżetowy władz lokalnych ma wpływ na finansowanie personelu, sprzętu i działań służących egzekwowaniu przepisów ochrony środowiska. Duży nacisk na wspieranie wzrostu gospodarczego i trudności finansowe sprawiają, że miejscowe władze nie są skłonne do ponoszenia kosztów ochrony środowiska. Jedynie dla przykładu można wskazać sytuację jednego BOŚ w prowincji Henan. Generalnie BOŚ mają dwa główne źródła finansowania: (a) pochodzące od władz lokalnych i przeznaczone na operacyjne funkcjonowanie biura, np. wynagrodzenia, bieżące funkcjonowanie, (b) fundusze specjalne w założeniu przeznaczone na konkretne działania na rzecz ochrony środowiska (środki pochodzące $z$ budżetu centralnego i budżetu prowincji oraz $80 \%$ opłat za emisję pozostające w dyspozycji władz lokalnych). W przypadku BOŚ z prowincji Henan władze lokalne mogły zapewnić finansowanie z własnych środków jedynie wynagrodzeń około połowy personelu. Stąd konieczne było wykorzystanie środków pochodzących z opłat za emisję, które powinny być przeznaczane na konkretne projekty na rzecz ochrony środowiska. Posiłkowanie się środkami pochodzącymi z opłat na emisje nie stanowi przykładu jednostkowego (Qi, Zhang, 2014: 209-210). Sama tylko presja polityczna ma ograniczony wpływ, podczas gdy lokalne sprawy i możliwości implementacji polityki są utrudnione przez brak lokalnych zasobów finansowych. Uzupełniająco należy dodać, że wraz z wprowadzeniem do oceny urzędniczej celów ochrony środowiska sytuacja finansowa lokalnych BOŚ uległa umiarkowanej poprawie.

Luka implementacyjna na poziomie lokalnym odnosi się także do jakości danych monitoringu środowiska. Wagę tego zagadnienia podkreśla fakt, że dane monitoringu środowiska stanowią punkt wyjścia do podejmowana decyzji związanych z zarządzaniem środowiskiem. Tymczasem wiarygodność chińskich danych środowiskowych jest kwestionowana przez obserwatorów zarówno krajowych, jak i zagranicznych. Pomijając wpływ czynników politycznych na dokładność chińskich danych monitoringu środowiska, najczęściej zwraca się uwagę na czynniki natury technicznej i metodologicznej gromadzenia danych (różne metody pozyskiwania i analizy danych w poszczególnych stacjach pomiarowych) (Qin, 2016). Wypada przy tym 
zwrócić uwagę na dwa powody obaw co do rzetelności danych. Wskazuje się bowiem, że oficjalne dane monitoringu często wydają się nie doceniać kwestii środowiskowych w porównaniu z tymi pochodzącymi z innych źródeł. Odrzucanie krytyki albo traktowanie jej jako próby zdyskredytowania Chin lub ich przywództwa nie ma uzasadnienia, ponieważ krytyka ta pochodzi nie tylko z zagranicy, ale coraz częściej ze strony krajowych naukowców zatrudnionych przez stosowne agencje państwowe i instytuty badawcze (Bradsher, 2012: 1-18).

Jeśli chodzi o czynniki natury pozatechnicznej, to należy zwrócić uwagę na działanie poszczególnych aktorów polityki ekologicznej, jak również oddziaływanie poszczególnych instrumentów. Z badań (Brombal, 2017: 1-18) wynika, że biurokratyczny system zachęt, sprzeczne cele poszczególnych podmiotów, ideologizacja kwestii ekologicznych stanowią potencjalne źródła stronniczości w procesach monitorowania środowiska w Chinach. Jedynie dla przykładu można przywołać fakt, że postępy w karierze chińskich urzędników w dużej mierze uzależnione są od wskazanego wyżej systemu oceny kadrowej. Związek między odpowiednio „dobrymi wskaźnikami” a szansą na awans stanowi obszar wrażliwy dla chińskich urzędników, ponieważ od awansu zależy ich status ekonomiczny, społeczny, a nawet polityczny. Cai Yongshun uważa, że pogoń za osobistymi celami ze strony lokalnych urzędników jest czynnikiem prowadzącym do manipulacji statystykami (Yongshun, 2000: 783-805).

Chiny mają wciąż problem z niekontrolowanym zanieczyszczeniem (np. nielegalne zrzuty) z obiektów, które wyposażone są już w sprzęt kontrolujący zanieczyszczenie. Tego typu instalacje nie są zwyczajowo używane, aby obniżyć koszty, chyba że firma spodziewa się kontroli. Prowadzi to do wniosku, iż stosowane rozwiązania technologiczne pozostają ciągle podatne na manipulacje (Wang, 2013:367-439). Tymczasem firmy, które są częściej kontrolowane, zgłaszają więcej zanieczyszczeń, ponieważ już nie kontynuują procederu fałszowania danych. Przypomina to zabawę w chowanego, kiedy z każdym nowym rozwiązaniem (wymogiem) ustalonym na poziomie centralnym, dochodzi do kreatywnego lokalnego wdrożenia, głównie poprzez odpowiednią "modyfikację” dostępnych danych po to, aby zatuszować realną skalę zanieczyszczenia (Rooij, Zhu, Na, 2017: 588).

W świetle teorii odgórnego nurtu implementacji polityki publicznej kluczowa staje się odpowiedź na pytanie, w jakim stopniu idee rządu centralnego są do zaakceptowania przez społeczeństwo, do którego polityka ekologiczna jest adresowana. Trzeba zaznaczyć, że czym innym jest ogólna deklaracja zasadności dbania o otaczający ludzi ekosystem, a zupełnie odmienna jest rzeczywista postawa przekładająca się na konkretne działania podejmowane przez obywateli. Na to, że w Chinach taki rozdźwięk istnieje, wskazują dane samego Ministerstwa Ekologii i Środowiska. Otóż aż 92\% Chińczyków jest zdania, że sortowanie śmieci jest ważne dla ochrony 
środowiska. Jednocześnie tylko 30\% stwierdza, że robi to dobrze lub bardzo dobrze (Xie, 2019). Powyższe można potraktować jako punkt wyjścia do coraz szerszych działań władz ChRL w kierunku wspierania postaw prośrodowiskowych.

\section{Wnioski: Relacje między poszczególnymi aktorami implementacji a efekty polityki ochrony środowiska naturalnego w Chinach}

Ogląd doświadczeń wyniesionych z realizacji polityki ochrony środowiska naturalnego w Chinach wskazuje, że cele stawiane przez władze publiczne nie są w pełni realizowane w zakładanym tempie i zakresie. Główna przyczyna tego stanu rzeczy leży w sposobie wdrażania na szczeblu regionalnym i lokalnym decyzji podjętych przez władze centralne oraz ich adekwatności do warunków lokalnych. W ostatnich latach pojawiło się kilka rozwiązań w prawie, systemie administrowania, których zamierzeniem jest wypełnienie luki implementacji odpowiedzialnej za egzekwowanie prawa ochrony środowiska w Chinach (Rooij, Zhu, Na, 2017: 602). Każde z rozwiązań wykazuje potencjał, jak i istotne ograniczenia, co nie ułatwia jednoznacznej oceny ich zastosowania. $\mathrm{Z}$ jednej strony tendencje centralizacyjne mogły pomóc $\mathrm{w}$ zaostrzeniu i częstszym egzekwowaniu prawa. $Z$ drugiej strony zapędy te nie pozwoliły chińskim organom administracyjnym stać się skutecznymi w zmniejszaniu zanieczyszczenia. Nadal dominujący wpływ na egzekwowanie ochrony środowiska mają warunki ekonomiczne, w tym zależność od zanieczyszczających źródeł dochodów przemysłowych i ogólnej zamożności (Zhan, Lo, Tang, 2014: 1005-1035). Stąd założyć można, że prowincje legitymujące się niższym PKB i w których tradycyjny przemysł jest bardziej obecny, będą skłonne egzekwować mniej, a zarazem zanieczyszczać więcej.

Odpowiadając na pytania postawione na wstępie artykułu, należy stwierdzić, że władza centralna jest w stanie definiować cele polityki ekologicznej oraz formułować adekwatny system nadzoru w sposób częściowo ograniczony. Rozliczne mechanizmy kontroli oraz hierarchicznego nadzoru nie w pełni odpowiadają potrzebom w sytuacji, kiedy władza centralna ma ograniczone postrzeganie problemów, które stara się rozwiązać. Głównym puntem słabości jest nierzetelność przekazywanych informacji na temat środowiska wewnątrz systemu POŚ, tj. głównie z poziomu lokalnego na krajowy. Zazwyczaj jest tak, że decyzje polityczne podejmowane są na podstawie ograniczonych informacji na temat skali i charakterystyki problemu, tutaj zniekształcona percepcja wydaje się kluczowa. Pozytywnie ocenić natomiast można działania związane z tworzeniem doktryny ekologicznej w Państwie Środka, która na poziomie 
subnarodowym czy lokalnym stanowi istotny instrument nacisku na wdrażanie standardów ekologicznych. Na każdym z poziomów implementacji polityki ochrony środowiska nie udało się rozstrzygnąć występującego także w innych krajach dylematu między ekonomią a ekologią. Nawet jeśli w wielu przypadkach można wskazać obszary synergii w zasygnalizowanej dychotomii, odpowiedź władzy centralnej - o lokalnej nie wspominając - nie jest wystarczająco klarowna. W krajach Zachodu dylemat ten rozstrzyga się poprzez stosowanie standardów ochrony środowiska zapisanych w prawie, tymczasem w Chinach przy selektywnym stosowaniu prawa dylemat nadal pozostaje nierozstrzygnięty.

Skupiając się na odpowiedzi na drugie pytanie dotyczące percepcji władz lokalnych w zakresie celów polityki, należy skonstatować, że jest ona zróżnicowana i po części uzależniona od poziomu rozwoju danej struktury terytorialnej. W biedniejszych jednostkach podziału terytorialnego nadal mimo centralnego nacisku na ekologię liczą się takie kwestie, jak: wzrost gospodarczy, tworzenie nowych miejsc pracy czy spokój społeczny, a wszystko to nierzadko kosztem ochrony przyrody. Na poziomie lokalnym mamy zatem do czynienia z poszukiwaniem winnego niepełnego wdrażania polityki ochrony środowiska. Najczęściej wskazuje się na lokalne BOŚ, które powszechnie uważane są za instytucje mało skuteczne. Tymczasem przez lata system ochrony, który nie stanowił dla lokalnych władz partyjnych priorytetu, pozostaje niedofinansowany. Władza lokalna, która boryka się z rosnącymi wydatkami budżetowymi i malejącymi wpływami, nie jest skłonna do przeznaczania większych środków na BOŚ. Z kolei trudno oczekiwać od BOŚ egzekwowania standardów ochrony, skoro cierpią na chroniczne niedofinansowanie. Sytuacja częściowo zmienia się w dobrym kierunku ze względu na fakt, że zasoby kadrowe BOŚ są uzupełniane, a finansowanie zwiększane, jednak proces ten nie został zakończony. Wskazane przykłady uzupełniania wsparcia finansowego dla lokalnych kadr ochrony środowiska przy odpowiednim nadzorze stanowią dobry punkt wyjścia. Powyższe stanowi też odpowiedź na trzecie pytanie postawione na wstępie, a odnoszące się do warunków, w jakich na poziomie lokalnym miejscowa władza jest $\mathrm{w}$ stanie $\mathrm{w}$ pełni wdrażać centralnie zaprojektowaną POŚ.

Interakcja między różnymi poziomami władzy, tj. centrum-struktury subnarodowe-władze lokalne, mimo wertykalnego nadzoru przynosi wiele przykładów zniekształcenia POŚ. Jednym z głównych elementów jest brak implementacji lub niepełne implementowanie prawa ochrony środowiska, odstępstwo od wymierzania kar w pełnym zakresie i wymiarze, obwinianie innych podmiotów odpowiedzialnych za ochronę środowiska czy raportowanie nierzetelnych danych środowiskowych. Wymiar polityczny ma tutaj również znaczenie, ponieważ poza wskazywanymi dysfunkcjami lokalnych BOŚ powodów niepełnej implementacji upatrywać należy w postawie 
lokalnych liderów KPCh. Potwierdza się w ten sposób poczynione na wstępie spostrzeżenie, że o (braku) efektywności polityki ekologicznej w Państwie Środka decydują nie tylko takie, a nie inne prerogatywy poszczególnych aktorów na różnych poziomach implementacji polityki, ale także ich interakcja.

\section{Bibliografia}

Ahlers, A.L., Heberer, T., Schubert, G. (2019). The Critical Role of Local Governance in China's Political. W: The Palgrave Handbook of Local Governance in Contemporary China: 73-93, J. Yu, S. Guo (eds.). Singapore: Palgrave.

Andersson, K.P., Ostrom, E. (2008). Analyzing decentralized resource regimes from a polycentric perspective. Policy Sciences, 41(1): 71-93.

Andersson, Y., Jin, H., Zhang S. (2016). Air Pollution Control Policies in China: A Retrospective and Prospects. International Journal Environmental Research and Public Health, December, 13: $1-22$.

Ang, Y.Y. (2017). Beyond Weber: Conceptualizing an alternative ideal type of bureaucracy in developing contexts. Regulation \& Governance, 11: 282-298.

Beer, A. (2017). Multilevel Governance. W: International Encyclopedia of Geography: People, the Earth, Environment and Technology: 4571-4578. N. Castree, M.F. Goodchild, A. Kobayashi, W. Liu, R.A. Marston (eds.). Oxford: John Wiley \& Sons.

Bradsher, K. (2012). China Asks Other Nations Not to Release Its Air Data. New York Times, June 5, 2012, https://www.nytimes.com/2012/06/06/world/asia/china-asks-embassies-tostop-measuring-air-pollution.html?_r=0 (dostęp: 15.05.2020).

Brombal, D. (2017). Accuracy of environmental monitoring in China: Exploring the influence of institutional, political and ideological factors. Sustainability, 9: 2-18.

Cai, H., Treisman, D. (2006). Did Government Decentralization Cause China's Economic Miracle? World Politics, 58(4): 505-535.

Constitution (2004). Constitution of the People's Republic of China (full text after amendment on March 14, 2004), http://www.npc.gov.cn/englishnpc/Constitution/2007-11/15/content_ 1372963.htm (dostęp: 15.05.2020).

Environmental Protection Law. Environmental Protection Law of the People's Republic of China, http://english.mee.gov.cn/Resources/laws/environmental_laws/200710/t20071009_109928. shtml (dostęp: 15.05.2020).

Gacek, Ł. (2016). „Cywilizacja ekologiczna” we współczesnych Chinach: polityka ochrony środowiska w postulatach strategii zrównoważonego rozwoju. W: Perspektywy i bariery rozwoju chińskiej gospodarki: 62-88. J. Marszałek-Kawa (red.). Toruń: Adam Marszałek.

Gang, C. (2009). Politics of China's Environmental Protection: Problems and Progress. Singapore: World Scientific.

Guttman D., Song Y. (2007). Making central-local relations work: Comparing America and China environmental governance systems. Frontiers of Environmental Science \& Engineering in China, 4: 418-433. 
He, G., Lu, Y., Mol, A.P.J., Beckers, T. (2012). Changes and challenges: China's environmental management in transition. Environmental Development, 3: 25-38.

Heberer, T. (2019). Local Cadres, W: The Palgrave Handbook of Local Governance in Contemporary China: 157-178, J. Yu, S. Guo (eds.). Singapore: Palgrave.

Heilmann, S. (2008). From local experiments to national policy: The origins of China's distinctive policy process. The China Journal, 59 (January): 1-30.

Heilmann, S., Melton, O. (2013). The reinvention of development planning in China, 1993-2012. Modern China, 39(6): 580-628.

Hill, M., Hupe, P. (2012). Implementing Public Policy: Governance in Theory and in Practice. Thousand Oaks, London, New Delhi: SAGE Publications.

Huang, X., Kim, S.E. (2020). When top-down meets bottom-up: Local adoption of social policy reform in China. Governance, 33(2): 343-364.

Kostka, G. (2014). Authoritarian Environmentalism Undermined? Local Leaders' Time Horizons and Environmental Policy Implementation in China. The China Quarterly, 218 (June): 359-380.

Kostka, G., Nahm, J. (2017). Central-Local Relations: Recentralization and Environmental Governance in China. The China Quarterly, 231 (September): 567-582.

Kostka, G., Zhang, C. (2018). Tightening the grip: environmental governance under Xi Jinping. Environmental Politics, 27: 769-781.

Kraft, M.E. (2015). Environmental policy and politics. New Jersey: Pearson.

Li, H., Zhou, L. (2005). Political turnover and economic performance: the incentive role of personnel control in China. Journal of Public Economics, 89: 1743-1762.

Liu, B. (2003). Improving the Quality of Public Policy-making in China: Problems and Prospects. Public Administration Quarterly, 27(1/2): 125-141.

Lorentzen, P., Landry, P., Yasuda J. (2014). Undermining authoritarian innovation: The power of China's industrial giants. The Journal of Politics, 76(1): 182-194.

Ministry of Finance of the People's Republic of China (2011). China Finance Yearbook of 2011. Financial Publishing House of China: Beijing, za: Y. Qi, L. Zhang, Local Environmental Enforcement Constrained by Central-Local Relations in China. Environmental Policy and Governance, 24: 216-232.

Mol, A. (2009). Urban environmental governance innovations in China. Current Opinion in Environmental Sustainability, 1(1): 96-100.

Monti, F. (2016). Chinese Environmental Protection: Between National Laws and Governance System. W: China and Europe's Partnership for a More Sustainable World: 145-158. F. Spigarelli, L. Curran, A. Arteconi (eds.). Bingley: Emerald.

Ongaro, E., Gong, T., Jing, Y. (2019). Toward Multi-Level Governance in China? Coping with complex public affairs across jurisdictions and organizations. Public Policy and Administration, 34(2): 105-120.

Parsons, W. (1995). Public Policy: An Introduction to the Theory and Practice of Policy Analysis. London: Edward Elgar Publishing. 
Pülzl, H., Treib, O. (2007). Implementing Public Policy. W: Handbook of Public Policy Analysis: Theory, Politics, and Methods: 89-108. F. Fischer, G.J. Miller (eds.). London, New York, NY: Routledge.

Qi, Y., Zhang L. (2014). Local Environmental Enforcement Constrained by Central-Local Relations in China. Environmental Policy and Governance, 24: 216-232.

Qin, L. (2016). Clear as mud: how poor data is thwarting China's water clean-up. China Dialogue, 18 May 2016, https://www.chinadialogue.net/article/show/single/en/8922-Clear-as-mudhow-poor-data-is-thwarting-China-s-water-clean-up (dostęp: 15.05.2020).

Qin, T. (2007). China's Peaceful Development and Global Climate Change: A Legal Perspective. Law, Environment and Development Journal, 3(1): 56-69.

Ran, R. (2013). Perverse incentive structure and policy implementation gap in China's local environmental politics. Journal of Environmental Policy \& Planning, 15(1):17-39.

Ran, R. (2017). Understanding Blame Politics in China's Decentralized System of Environmental Governance: Actors, Strategies and Context. The China Quarterly, 231: 634-661.

Rooij, van B. (2003). Environmental law enforcement in Sichuan: organization and procedure in comparative perspective. China Information, 17(2): 36-64.

Rooij, van B. (2006). Regulating Land and Pollution in China: Lawmaking, Compliance, and Enforcement: Theory and Cases. Leiden: Amsterdam University Press.

Rooij, van B. (2010). The people vs. pollution: understanding citizen action against pollution in China. The Journal of Contemporary China, 19(63): 55-77.

Rooij, van B., Zhu Q., Na L., Qiliang W. (2017). Centralizing Trends and Pollution Law Enforcement in China. The China Quarterly, 231: 1-24.

Sigman, H. (2014). Decentralization and environmental quality: an international analysis of water pollution levels and variation. Land Economics, 90(1): 1-31.

Smith, K., Larimer, Ch. (2017). The Public Policy and Theory Primer. Boulder: Routledge.

Swanson, K.E., Kuhn R.G., Xu W. (2001). Environmental policy implementation in rural China: a case study of Yuhang, Zhejiang. Environmental Management, 27 (4): 481-491.

Świstak, M. (2018). Polityka regionalna jako polityka publiczna. Wobec potrzeby optymalizacji publicznego działania. Kraków: Wydawnictwo UJ.

Świstak, M. (2019). Polityka rozwoju społeczno-gospodarczego a wyzwania rozwojowe Chin. W: Azjatycki model rozwoju społeczno-gospodarczego. Wybrane aspekty w świetle standardów i doświadczeń Unii Europejskiej: 117-149. M. Świstak, J. Tkaczyński (red.). Kraków: Wydawnictwo UJ.

Wang, A. (2013). The search for sustainable legitimacy: environmental law and bureaucracy in China. Harvard Environmental Law Review, 37(2): 367-438.

Weibust I. (2016). Green Leviathan: The Case for a Federal Role in Environmental Policy. London, New York: Ashgate.

Wong C., Karplus V.J. (2017). China’s War on Air Pollution: Can Existing Governance Structures Support New Ambitions?. The China Quarterly, 231: 662-684. 
Xie, E. (2019). Can China sort its household waste recycling problem by 2020?. South China Morning Post, May 29, https://www.scmp.com/news/china/politics/article/3015647/canchina-sort-its-household-waste-recycling-problem-2020 (dostęp: 15.05.2020).

Yi, H., Huang, C., Chen, T., Xu, X., Liu, W. (2016). Multilevel environmental governance: Vertical and horizontal influences in local policy networks. Sustainability, 11(8): 1-13.

Yongshun, C. (2000). Between State and Peasant: Local Cadres and Statistical Reporting in Rural China. The China Quarterly, 163: 783-805.

Young, O.R., Guttman, D., Qi Y., Bachus, K., Belis, D., Cheng, H., Lin, A., Schreifels, J., Eynde, S.V., Wang, Y., Wu, L., Yan, Y., Yu, A., Zaelke, D., Zhang, B., Zhang, S., Zhao, X., Zhu, X. (2015). Institutionalized governance processes: Comparing environmental problem solving in China and the United States. Global Environmental Change, 31: 163-173.

Zhan, X., Lo, C., W.H., Tang, S.Y. (2014). Contextual changes and environmental policy implementation: A longitudinal study of street-level bureaucrats in Guangzhou, China. Journal of Public Administration Research and Theory, 24(4): 1005-1035.

Zhilin, M., Shuchun, B., Bing, X. (2014). Environmental Legislation in China: Achievements, Challenges and Trends. Sustainability, 6: 1-13. 